\title{
Comparison of Drought Indices in the Rio Minho Watershed, Jamaica
}

\author{
Comparação de Índices de Seca na Bacia do Rio Minho na Jamaica
}

Comparación de Índices de Sequía en la Cuenca del Río Minho en Jamaica

\author{
Sheika Tamara Henry ${ }^{1}$
}

\begin{abstract}
The impact of extreme weather events on the agricultural sector in Jamaica is a reason for concern, as it threatens food security and the livelihood of many small farmers. Considering the most recent projections for a reduction in rainfall, along with higher temperatures due to climate change, there is the need for studies concerning drought at the watershed level, as the phenomenon is more localized in comparison to other events. With this in mind, the aim of this study is to compare meteorological and hydrological drought within the Rio Minho Watershed between 1970 and 2014. Results show periods of wet conditions followed by dry conditions for both meteorological and hydrological data. While meteorological drought dominates in terms of occurrence, hydrological drought demonstrated a longer duration. Results from this study will provide a greater understanding as it relates to the drought conditions and the need for water harvesting.
\end{abstract}

KEYWORDS: Beckford Kraal. Extreme weather events. DrinC.

RESUMO: O impacto de eventos climáticos extremos no setor agrícola jamaicano é motivo de preocupação, pois ameaça a segurança alimentar e o sustento de muitos agricultores. Considerando as projeções mais recentes de redução de chuvas e as altas temperaturas causadas, em grande medida, pelas mudanças climáticas, evidenciou-se a necessidade de estudos que tragam em seu escopo o debate a cerca da seca em nível de bacias hidrográficas, já que o fenômeno é mais localizado que outros eventos climáticos. Com isto em mente, busca-se, nesta pesquisa, comparar a seca meteorológica e hidrológica na Bacia Hidrográfica do Rio Minho entre 1970 e 2014. Os resultados mostram períodos de condições úmidas seguidas de condições secas para ambos os dados meteorológicos e hidrológicos. Enquanto a seca meteorológica domina em termos de ocorrência, a seca hidrológica demonstrou uma duração temporal mais longa. Esses resultados podem contribuir com as reflexões sobre as condições de seca e à necessidade de coleta de água na Jamaica.

PALAVRAS-CHAVE: Beckford Kraal. Eventos climáticos extremos. DrinC.

RESUMEN: El impacto de los fenómenos meteorológicos extremos en el sector agrícola en Jamaica es motivo de preocupación, debido a su amenaza frente a la seguridad alimentaria y consigo, el sustento de los pequeños agricultores. Considerando las proyecciones más recientes sobre la

\footnotetext{
${ }^{1}$ Universidade Federal do Paraná. Av. Cel. Francisco H dos Santos, 100 - Ed. João José Bigarella - 1ํandar sala 108, Jardim das Américas, Curitiba, CEP: 81531-980. henrytsheika@gmail.com.
} 
reducción de las precipitaciones y aumento de las temperaturas producto del cambio climático, es necesario realizar estudios sobre la sequía a nivel de la cuenca porque el efecto de los otros eventos sobre las áreas es mayor en inundaciones que en sequías. Por lo anterior, el objetivo de este estudio es comparar la sequía meteorológica e hidrológica dentro de la cuenca del Río Minho entre 1970 y 2014. Los resultados muestran períodos de condiciones húmedas seguidas de condiciones secas tanto para datos meteorológicos como hidrológicos. Mientras que la sequía meteorológica predomina en términos de ocurrencia, la sequía hidrológica demostró mayor duración. Los resultados de este estudio proporcionarán una mayor comprensión en relación con las condiciones de sequía y la necesidad de la recolección de agua.

PALABRAS-CLAVE: Beckford Kraal. Eventos climáticos extremos. DrinC.

\section{INTRODUCTION}

Climate variability has changed the dynamics of extreme weather events across the globe. According to Ebi and Bowen (2016), the recovery time for extreme events has been reduced due to the increase in their occurrence over the years. Up to 1949, about 484 natural hazards were documented worldwide compared to approximately 14,039 from 1950 to 2017 (EM-DAT, 2018). The increase in events such as droughts, precipitation and cyclones has been linked to human activity as demonstrated in the Fourth Assessment Report of the IPCC (MEEHL et al., 2007). Furthermore, the Fifth Assessment Report highlighted the likelihood of a reduced but greater occurrence of intense precipitation and higher temperatures in mid-latitudes and over tropical regions by the end of the century because of human induced global warming (QIN et al., 2007).

Similar to global trends, the frequency and intensity of extreme events in Jamaica has increased (FULTON, 2013). Approximately 16 events were recorded between 1900 and 1944 while about 40 events have been registered since the 1950s for the island (EM-DAT, 2018). While floods have affected Jamaica at a larger scale, drought has a more localized impact especially on southern parishes situated within the rain shadow. The impact of drought is particularly devastating to the agricultural sector as about $10 \%$ of farmlands have access to irrigation (TROTMAN et al., 2009). Some of the factors that increase vulnerability to drought include: national reliance on agriculture, small farmers dependent on rainfall for irrigation and the increase in the demand for water supply due to urbanization (FULTON, 2013).

Despite the need for swift mitigation actions internationally and locally, analysis of extreme weather events has been challenging due to paucity in long term climatic data in some countries (MEEHL et al., 2007). This is further compounded by variation in the definitions and approaches used to assess these events. Drought is an example of such hazards with the lack of an agreed definition and method for analysis, which hinders 
research on the phenomenon (YEVJEVICH, 1967). Actually, over 150 definitions of drought have been noted by Wilhite and Glantz (1985). However, as elaborated by Otkin et al. (2018), the occurrence of drought at different scales and in different environments makes the use of a single definition unrealistic hence, it is important to have different classification.

Within this regard, drought can be classified as: meteorological, agricultural, hydrological, socio-economic (WILHITE; GLANTZ, 1985), ecological (CRAUSBAY; RAMIREZ ${ }_{1}$ 2017) or as flash drought. While meteorological drought is often characterized from a deficit in precipitation below normal values, hydrological drought takes place when groundwater and stream flow are below the long term mean. On the other hand, agricultural drought occurs when there is a reduction in soil moisture of a particular plant at a specific point in time and socio-economic drought is associated with economic impacts caused from a lack of water supply due to a reduction in rainfall. Moreover, ecological drought refers to an episodic deficit in water availability that drives ecosystems beyond thresholds of vulnerability, impacts ecosystem services, and triggers feedbacks in natural and or human systems (CRAUSBAY; RAMIREZ, 2017). Information regarding the types of indices used for analyzing drought can be obtained from the (WMO) World Meteorological Organization and (GWP) Global Water Partnership (2016).

Due to the catastrophic nature of drought, there is the need for drought assessments at various scales (WILHITE, 2000). Within this context, the aim of this study is to compare hydrological and meteorological drought within the Rio Minho Watershed in Jamaica from 1970-2014 at different time scales. Richards (2010) conducted a previous study using the Standardized Precipitation Index (SPI) in the watershed for the period 1971 to 2008 however; the use of the Stream Drought Index (SDI) was not considered and was one of the recommendations for further analysis. Furthermore, the incorporation of the Decile Index based on an annual timescale will provide a new approach for analyzing drought within the watershed.

\section{STUDY AREA}

The Rio Minho Watershed is located within the parish of Clarendon, Jamaica (Figure 1). Mean annual temperature between 2004 and 2008 was estimated at $22.08^{\circ} \mathrm{C}$ at the Mason River Station while the mean annual rainfall from 1970-2014 was approximately $1,676.02 \mathrm{~mm}$ at the Beckford Kraal Weather Station (METEOROLOGICAL SERVICE OF JAMAICA, 2015).

The main river (Rio Minho) flows from steep slopes in the north in a southwardly direction to lowlands formed by alluvial deposits towards the sea (WATER RESOURCES AUTHORITY, 2019). In this region, plantation crops (sugarcane, coffee, yam, citrus and 
banana), shrimp farming, fishing, sand mining and bauxite are the main economic activities.

The stations used in this study are presented in Table 1.

Figure 1 - Location of the Study Area

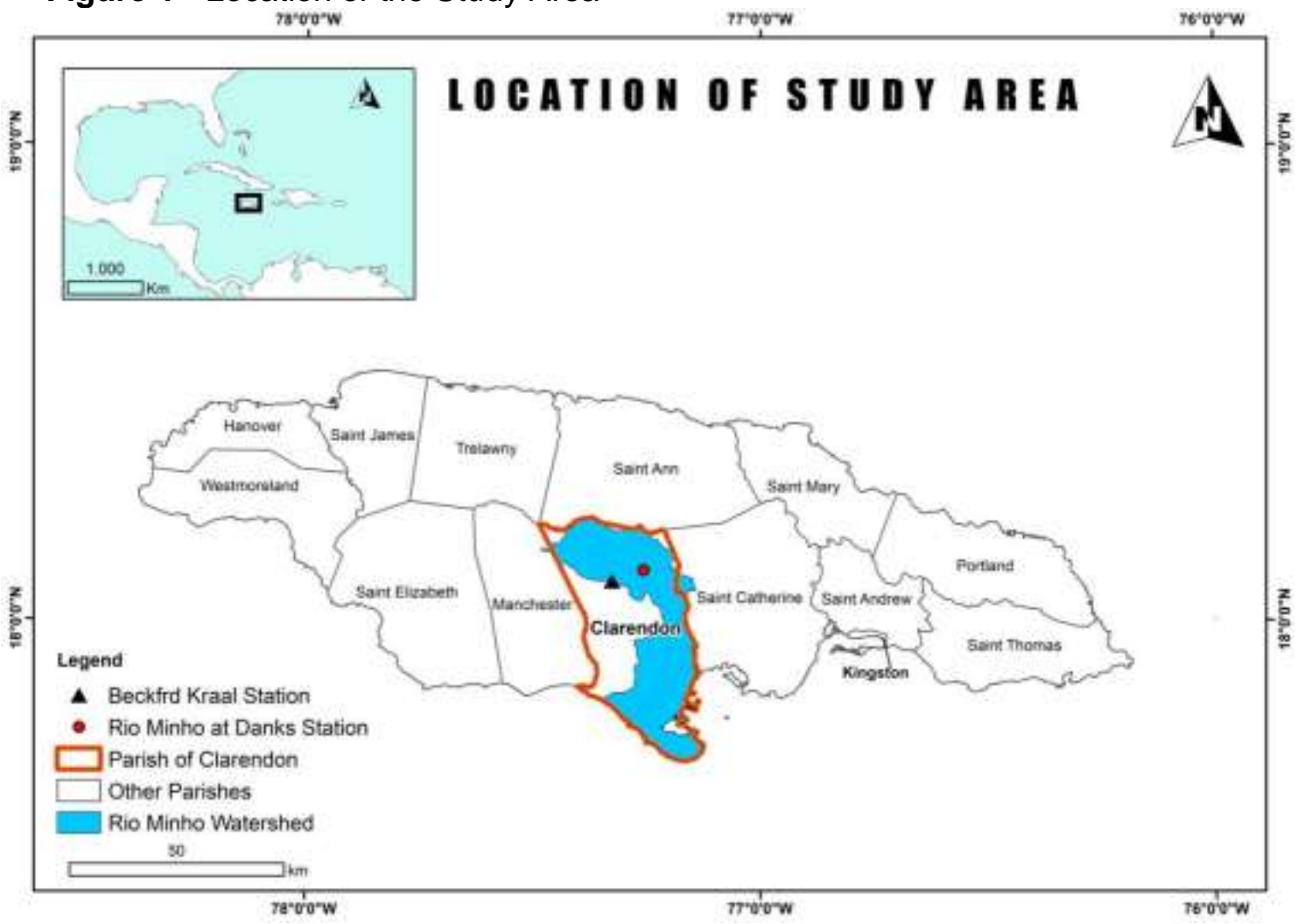

Source: Adapted by: Henry (2019) from Diva-Gis (2019) and Water Resources Authority (2019).

Table 1 - Rainfall and Hydrological Stations

\begin{tabular}{|c|c|c|c|c|c|c|}
\hline Station & Type & Period & Latitude & Longitude & $\begin{array}{l}\text { Drainage } \\
\text { Area }(\mathrm{km})\end{array}$ & $\begin{array}{l}\text { Elevation } \\
\text { (m) }\end{array}$ \\
\hline $\begin{array}{l}\text { Beckford } \\
\text { Kraal }\end{array}$ & Rainfall & $1970-2014$ & $18^{\circ} 04^{\prime} 42^{\prime \prime} \mathrm{N}$ & $\begin{array}{l}77^{\circ} 18^{\prime} 16^{\prime \prime} \\
W\end{array}$ & $\mathrm{~N} / \mathrm{A}$ & 472.4 \\
\hline $\begin{array}{l}\text { Rio Minho } \\
\text { at Danks }\end{array}$ & Discharge & $1970-2014$ & $18^{\circ} 10^{\prime} 64^{\prime \prime} 03$ & $\begin{array}{l}77 \stackrel{0}{2} 25^{\prime} \\
71^{\prime \prime} 47\end{array}$ & 216 & 168 \\
\hline
\end{tabular}

Source: Adapted by: Henry (2019) from Water Resources Authority (2019).

\section{MATERIALS AND METHODS}

The monthly rainfall data for the Beckford Kraal Weather Station for the period 1970 to 2014 was acquired from The Meteorological Service of Jamaica however, the streamflow data for the same period was provided by the Water Resources Authority (2019). First, the NIPALS (Nonlinear Iterative Partial Least Squares) algorithm in XLSTAT was used to compute the missing data in the precipitation dataset (WOLD, 1973). Afterwards, further analysis was conducted using the Pettitt's test to check for data homogeneity (PETTITT, 1979) for quality control. Next, the data was prepared in Excel for computation of the SPI 
(MCKEE; DOESKEN; KLEIST, 1993), SDI (NALBANTIS; TSAKIRIS, 2008) and the Decile Index (DI), (GIBBS; MAHER, 1967) using the Drought Indices Calculator (DrinC) open source software. DrinC was developed by the Centre for the Assessment of Natural Hazards and Proactive Planning and the Laboratory of Reclamation Works and Water Resources Management of the National Technical University of Athens (TIGKAS; VANGELIS; TSAKIRIS, 2013). Further information regarding the computation of the indices can be obtained from Giddings et al. (2005).

Both the SDI and SPI were computed based on 3, 6, 9 and 12 monthly time scales (WORLD METEOROLOGICAL ORGANIZATION; GLOBAL WATER PARTNERSHIP, 2016) with the use of the gamma distribution technique as it is known to provide a better fit for rainfall time series data (BORDI; SUTERA, 2007). The 3-month timescale ranged from October to December (Oct-Dec) while the 6-month timescale incorporated the months of October to March (Mar). The 9-month timescale included Oct to June (June). In addition, the 12-month timescale was calculated from October to September (Sep). One of the main differences between the SDI and SPI is that, the prior uses stream flow data and the other requires rainfall data to analyze drought (WORLD METEOROLOGICAL ORGANIZATION; GLOBAL WATER PARTNERSHIP, 2016).

The SPI and SDI both use a threshold from +2 to -2 or less to characterize wet and dry periods respectively (Table 2). With this method, surplus rainfall and discharge data are indicated by positive values whereas a negative SPI and SDI signify dry periods. However, only values of -1.0 and less are classified as drought.

Table 2 - SPI and SDI Classification

\section{SPI and SDI Values}

\section{Classification}

\section{$2.0+$}

1.5 to 1.99

1.0 to 1.49

-99 to .99

-1.0 to -1.49

-1.5 to -1.99

-2 and less
Extremely Wet

Very Wet

Moderately Wet

Near Normal

Moderately Dry

Severely Dry

Extremely Dry

Source: Tsakiris and Vangelis (2004). 
As it relates to the $\mathrm{DI}$, monthly rainfall values are computed into tenths of the distribution or deciles arranged into ten different thresholds. The lowest precipitation values are placed in the first and second deciles while the median can be found in the fifth Decile. Finally, deciles are arranged into five different classes as shown in Table 3.

Table 3 - Decile Classification

\begin{tabular}{ll}
\hline Decile Classification & Description \\
\hline Deciles 1-2: lowest 20\% & Much below normal \\
Deciles 3-4: next lowest 20\% & Below normal \\
Deciles 5-6: middle 20\% & Near normal \\
Deciles 7-8: next highest 20\% & Above normal \\
Deciles 9-10: highest 20\% & Much above normal \\
\hline
\end{tabular}

Source: Tigkas, Vangelis e Tsakiris (2013).

\section{RESULTS - METEOROLOGICAL DROUGHT}

From the Decile Index, 9 major periods of drought are shown between 1970 and 2014 (Figure 2). The first period categorized as 'much below normal event' commenced from 1971 to 1972 with the second episode in 1974, which lasted up until 1977. Likewise, other events occurred in the mid-1980s, between 1996 and 1998 along with isolated phases in the early 2000 s and 2014.

Figure 2 - Decile Index for Beckford Kraal 1970-2014

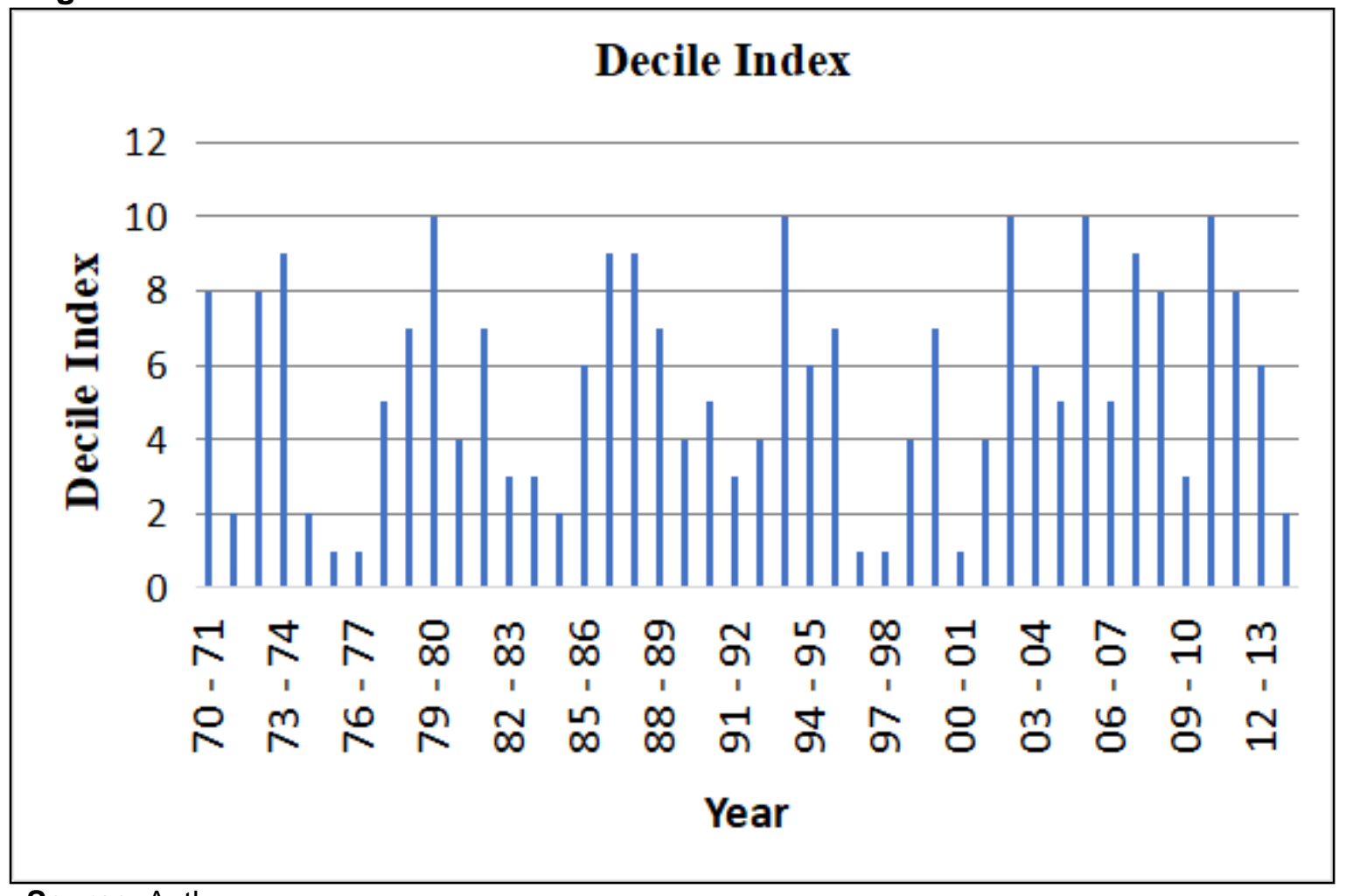

Source: Author 
However, the 'much above normal' episodes, indicative of very wet conditions, took place from the mid to late 70 s up to the 2000s. The SPI analysis (Figure 3) shows that the occurrence of extreme events varies at different time scales. Severe drought took place only in 1975-1978, 1982-1985, 2004-2005, and 2013-2014. Even though the number of dry conditions for the 3-month SPI exceeded the other time scales, greater severity was observed for the 6-months, 9-month and 12-month SPI. For example, only 9 moderately dry and 1 severely dry conditions were recorded for the 3-month SPI while about 4 moderately dry and 4 severely dry periods were detected for the 5-month SPI. Also, for the 9-month SPI, 3 moderately dry and 4 severely dry episodes were noticed. However, 7 moderately dry and 2 severely dry events were identified for the 12-month SPI.

Figure 3 - SPI Values for Beckford Kraal from 1970-2014

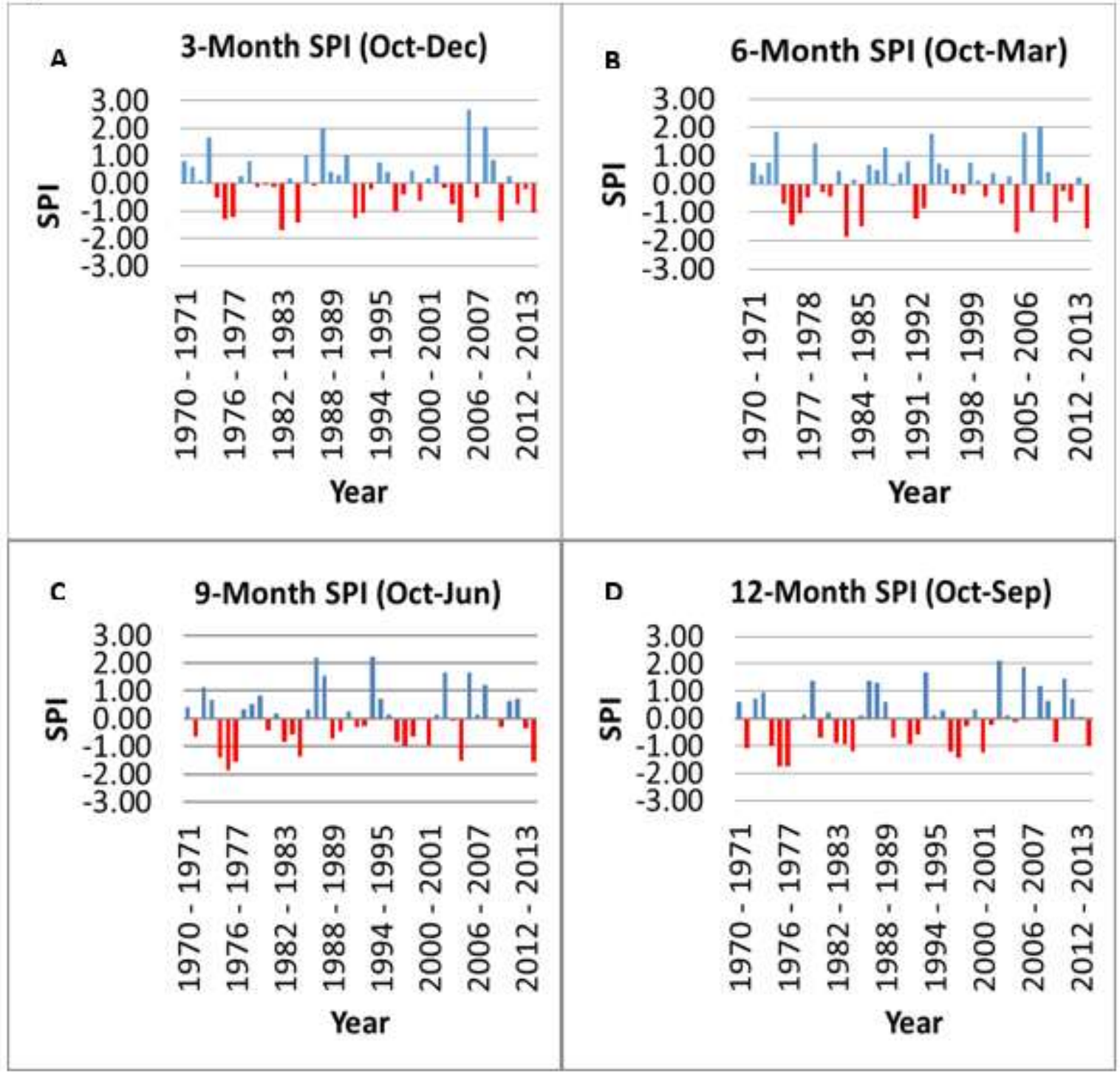

3-month SPI-Oct-Dec (A), 6-month SPI Oct-Mar (B), 9-month SPI-Oct-Jun (C) and 12-month SPI Oct-Sep (D).

Source: Author 
Historical droughts for the 3-month SPI were recorded in 1975-1977, 1982-1985, 1991 1993, 1996-1997, 2004-2005, 2009-2010 and 2013-2014. Besides, the 6-month SPI occurred during 1975-1977, 1982-1983, 1984-1985, 1991-1992, 2004-2007 and 2009 to 2010. Moreover, water deficit years for the 9-month SPI included: 1974-1977, 1984-1985, 1997-1998, 2004-2005 and 2013-2014. Likewise, the 12-month SPI drought occurred in 1971-1972, 1974-1978, 1984-1985, 1996-1998, 2000-2001 and 2013-2014.

In the SDI analysis (Figure 4), only one record of extremely dry condition (1976-1977) was observed while about 8 severely dry phases took place $(1975-1978,1983-1984,1997-$ 1998 and 2009-2010). With regards to extremely wet conditions, the years 1986-1988 and 2005-2006 are highlighted. Specifically, the 3 and 6 monthly SDI recorded the same number (7) of moderately dry conditions however, about 6 dry phases occurred for the 12 monthly SDI and 5 for the 9 monthly time scale.

The results from the stream flow and meteorological drought based on the moderate to extreme classification are listed in Table 4. The term intensity refers to the lowest value of the indices during the event while drought frequency is based on the total amount of event within a particular period (SPINONI et al., 2014).

Table 4 shows that the 15 stream flow drought episodes corresponded with the meteorological drought within the same period even though the number of occurrences for the latter was higher (22). In fact, the meteorological drought had a higher intensity (-3.05) which was recorded for 1997 to 1998. Nevertheless, the magnitude and frequency of stream flow drought seem to be greater for some years as demonstrated between 1997 and 1998. For example, while SPI recorded 3 dry events, about 9 months with dry spells were observed with the SDI for the aforementioned period. Apart from that, the month of March seems to be the most affected for the SPI while October is the recurrent month for the SDI. It is also important to note the occurrence of drought in the early and late rainfall season, which relates to May and October respectively.

To get a better understanding of the hydro-meteorological conditions within the watershed, the mean monthly rainfall and flow duration within the watershed from 1970-2014 are examined (Figure 5 and 6). As depicted in Figure 5, the lowest amount of rainfall occurs in February, March, July and December, which corresponds to the dry season when drought normally takes place. Moreover, the rainfall peaks in May and October reflect the early and late rainfall seasons respectively with wetter conditions.

The flow duration curve (Figure 6) shows the number of times discharge is equaled or exceeded for a given period. As illustrated, streamflow equaled or exceeded $1.09 \mathrm{~m}^{3} / \mathrm{s}$ for about $60 \%$ of the time while flows that exceeded $95 \%$ were estimated at $0.39 \mathrm{~m}^{3} / \mathrm{s}$. These percentiles illustrate the low streamflow at Rio Minho at Danks over the years and are indicative of the occurrence of drought within the watershed. 
Figure 4 - SDI Values for Danks from 1970-2014.

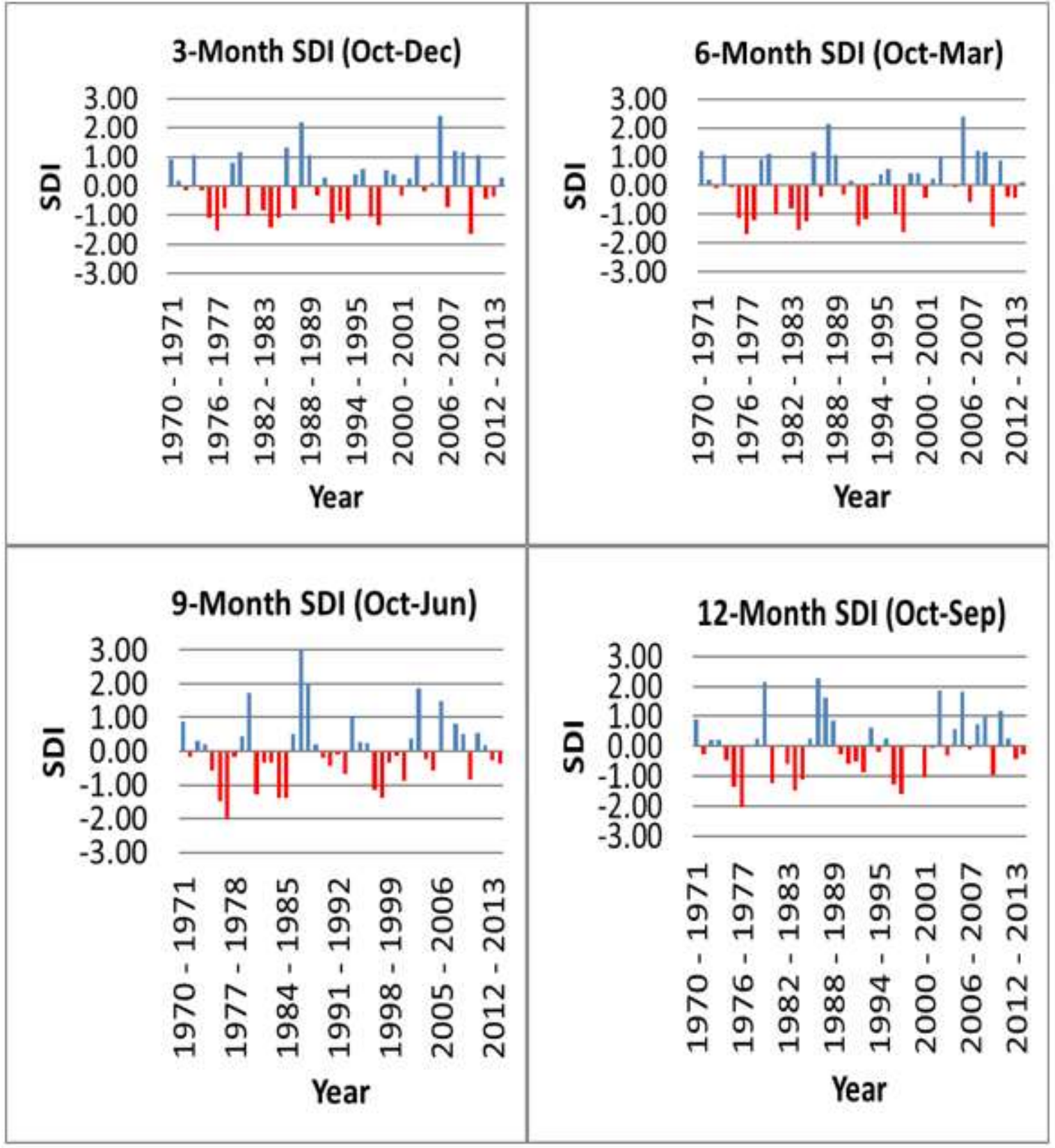

3- month SDI-Oct-Dec (A), 6-month SDI Oct-Mar (B), month SDI-Oct-Jun (C) and 12-month SDI Oct-Sep (D).

Source: Author 
Table 4 - Comparison of severe to extreme streamflow and meteorological drought 1990 2014

\begin{tabular}{|c|c|c|c|c|c|c|}
\hline \multicolumn{4}{|c|}{ SPI } & \multicolumn{3}{|c|}{ SDI } \\
\hline Year & Magnitude & Intensity & Frequency & Magnitude & Intensity & Frequency \\
\hline $1990-1991$ & -1.31 & -1.31 & (1) Aug & -1.09 & -1.09 & (1) May \\
\hline $1991-1992$ & -6.13 & -1.43 & $\begin{array}{l}\text { (5) Oct, Apr, } \\
\text { June, Aug, } \\
\text { Sep }\end{array}$ & -6.34 & -1.49 & $\begin{array}{l}\text { (5) Oct, } \\
\text { Dec, Feb, } \\
\text { Aug, Sep }\end{array}$ \\
\hline $1992-1993$ & -1.80 & -1.80 & (1) Jan & -2.88 & -1.50 & $\begin{array}{l}\text { (2) Jan to } \\
\text { Feb }\end{array}$ \\
\hline $1993-1994$ & -2.47 & -1.34 & (2) Oct, Aug & -1.19 & -1.19 & (1) Oct \\
\hline $1994-1995$ & -1.52 & -1.52 & (1) Jun & -3.73 & -1.46 & $\begin{array}{l}\text { (3) Oct, } \\
\text { Aug, Sep }\end{array}$ \\
\hline $1996-1997$ & -1.30 & -1.30 & (1) Dec & -2.12 & -2.12 & (1) $\mathrm{Dec}$ \\
\hline $1997-1998$ & -6.20 & -3.05 & $\begin{array}{l}\text { (3) Apr May } \\
\text { Jul }\end{array}$ & -11.16 & -1.62 & $\begin{array}{l}\text { (9) Oct, } \\
\text { Nov, Jan, } \\
\text { Feb, Apr, } \\
\text { May, Jul, } \\
\text { Aug, Sep }\end{array}$ \\
\hline $1998-1999$ & -3.02 & -1.94 & (2) May, Jun & -2.54 & -1.29 & (2) May, Jun \\
\hline $1999-2000$ & -1.29 & -1.29 & (1) Dec & -1.20 & -1.20 & (1) May \\
\hline $2000-2001$ & -5.25 & -2.31 & $\begin{array}{l}\text { (3) Feb, Mar, } \\
\text { Aug }\end{array}$ & -2.42 & -1.24 & (2) Nov, Aug \\
\hline $2001-2002$ & -2.64 & -1.44 & (2) June, Aug & -1.24 & -1.24 & (1) Sep \\
\hline $2002-2003$ & -3.36 & -1.17 & $\begin{array}{l}\text { (3) Feb, Mar, } \\
\text { Jul }\end{array}$ & $\mathrm{N} / \mathrm{A}$ & $\mathrm{N} / \mathrm{A}$ & $\mathrm{N} / \mathrm{A}$ \\
\hline $2003-2004$ & -1.16 & -1.00 & (1) Jul & $\mathrm{N} / \mathrm{A}$ & $\mathrm{N} / \mathrm{A}$ & $\mathrm{N} / \mathrm{A}$ \\
\hline $2004-2005$ & -3.67 & -2.36 & (2) Nov, Jun & -1.07 & -1.07 & Jun \\
\hline $2005-2006$ & -4.67 & -1.94 & $\begin{array}{l}\text { (3) Nov, Feb, } \\
\text { Mar }\end{array}$ & -1.11 & -1.11 & Mar \\
\hline $2006-2007$ & -2.40 & -1.37 & (2) Oct, Mar & $\mathrm{N} / \mathrm{A}$ & $\mathrm{N} / \mathrm{A}$ & $\mathrm{N} / \mathrm{A}$ \\
\hline $2007-2008$ & -1.39 & -1.39 & (1) Apr & $\mathrm{N} / \mathrm{A}$ & $\mathrm{N} / \mathrm{A}$ & $\mathrm{N} / \mathrm{A}$ \\
\hline $2008-2009$ & $\begin{array}{l}-1.33 \\
\end{array}$ & $\begin{array}{l}-1.33 \\
\end{array}$ & (1) Jan & $\mathrm{N} / \mathrm{A}$ & $\mathrm{N} / \mathrm{A}$ & $\mathrm{N} / \mathrm{A}$ \\
\hline $2009-2010$ & -5.36 & -1.47 & $\begin{array}{l}\text { (4) Oct, Jan, } \\
\text { Feb, Aug }\end{array}$ & -3.87 & -1.49 & $\begin{array}{l}\text { (3) Oct, } \\
\text { Nov, Dec }\end{array}$ \\
\hline $2010-2011$ & -2.03 & -1.03 & $\begin{array}{l}\text { (3) Nov, Feb, } \\
\text { Mar }\end{array}$ & -2.96 & -1.68 & (2) Feb, Mar \\
\hline $2011-2012$ & -3.99 & -2.66 & (2) Nov, Dec & $\mathrm{N} / \mathrm{A}$ & $\mathrm{N} / \mathrm{A}$ & $\mathrm{N} / \mathrm{A}$ \\
\hline $2013-2014$ & -3.64 & -1.46 & $\begin{array}{l}\text { (3) Oct, Mar, } \\
\text { Apr }\end{array}$ & $\mathrm{N} / \mathrm{A}$ & $\mathrm{N} / \mathrm{A}$ & $\mathrm{N} / \mathrm{A}$ \\
\hline
\end{tabular}

Source: Author 
Figure 5 - Mean Monthly Rainfall at Beckford Kraal $1970-2014$.

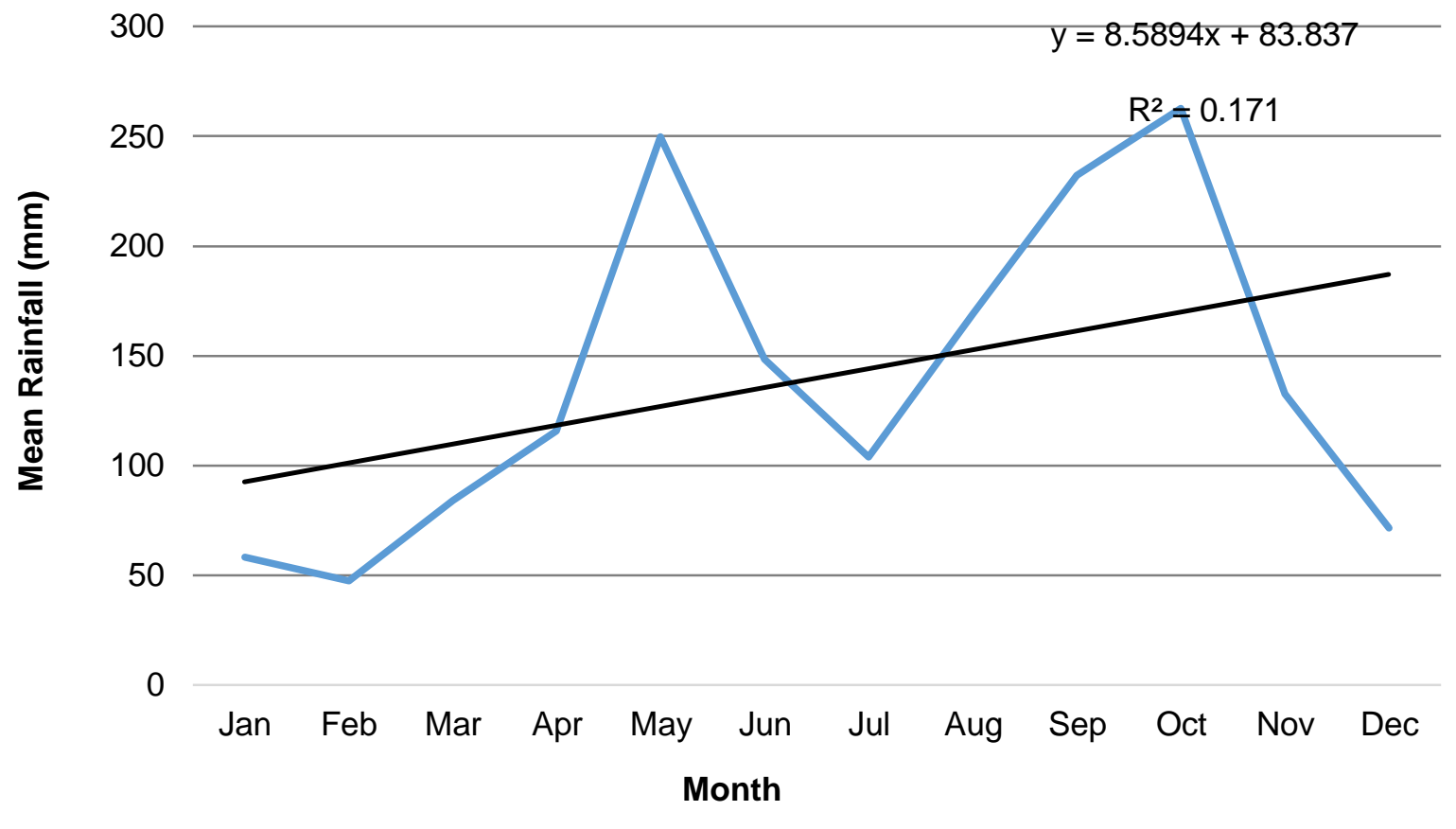

Source: Author

Figure 6 - Flow Duration Curve for Rio Minho at Danks 1970 - 2014

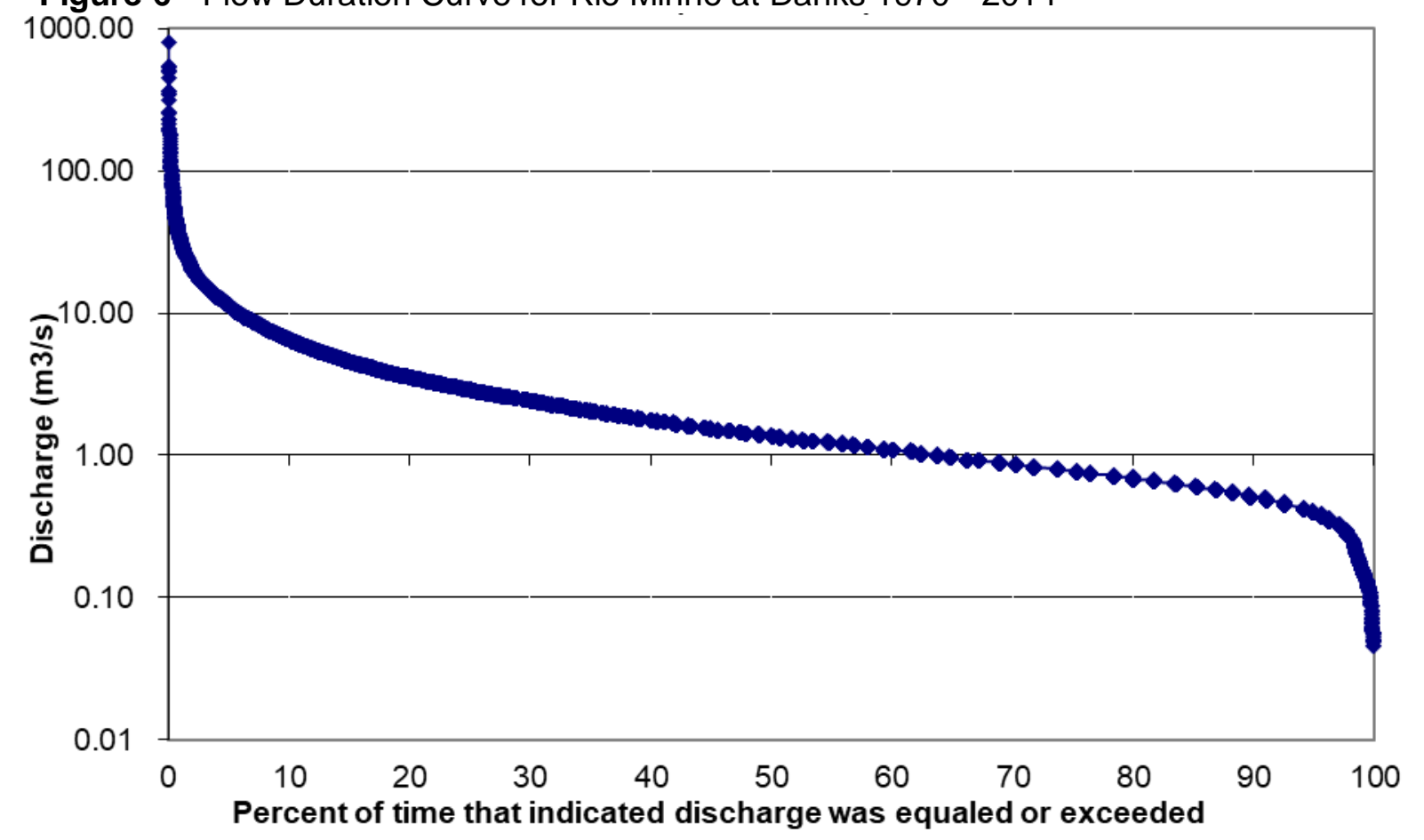

Source: Author 


\section{DISCUSSION}

The results indicate that while drought is a recurrent activity in Jamaica, the duration is short because the hydro-meteorological conditions are characterized by inter-annual variability. Within this regard, periods of rainfall are followed by dry conditions. It is important to note that the years with dry conditions are in accordance with reports about drought activity in Jamaica which dates back to as early as 1976 when rainfall fell below the 30 year average making it the worst event in over 10 years (THE DAILY GLEANER, 1987). Reports also indicated severe drought activity in 1985 in South Central Clarendon (THE DAILY GLEANER, 1985). Drought also occurred from 1996 to 1998 however, the most severe dry spell occurred between April and May in 1997 with normal rainfall below 31\% (THE DAILY GLEANER, 1996; 1997; 1998). Similarly, Campbell, Barker and McGregor (2011) had noted the presence of drought in 2004, 2005 and 2008. More recently, the impact of dry conditions was reflected in a decline in agricultural production which fell by about $6.5 \%$ for April to June 2013 (DROUGHT..., 2014).

Fluctuation in the hydro-meteorological variables presented is caused from the interference of many atmospheric systems which affect climate variability in Jamaica. However, according to Chen, Balloon and Taylor (2005), the El Nino Southern Oscillation (ENSO) generally influences drought in the Caribbean region. In the foregoing study, drought induced by ENSO occurred in 1972, 1976, 1982-1983, 1991 and 1997. On the other hand, decadal variability also resulted in drought (TAYLOR; ENFIELD; CHEN, 2002; THE UNIVERSITY OF THE WEST INDIES, 2014) like in 1976 and 1991 when rainfall went below the 30 year mean by $72 \%$ and $73 \%$ correspondingly (CHEN; FALLOON; TAYLOR, 2005). While La Nina influences rainfall in Jamaica, drought during its occurrence was noticed in the first rainfall season of the following year, as was the case in 1971, 1974, 19751 1985, 1989 and 2000 (CHEN; FALLOON; TAYLOR, 2005). It is evident that meteorological and hydrological droughts respond differently. According to Wilhite and Glantz (1985), hydrological droughts do not generally occur the same time as meteorological drought. Furthermore, hydrological drought might take place long after the ending of a meteorological drought.

\section{CONCLUSION}

The present study attempted to compare meteorological and hydrological drought indices using the DI, SPI and SDI within the Rio Minho Watershed in an effort to detect variation at different time scale. From the results, it is evident that the watershed is prone to extreme weather events such as drought and floods. The study found that all the indices 
used, provided a satisfactory overview of the drought conditions over the period analyzed. Furthermore, the results presented were in line with other studies. While the SPI recorded a higher frequency of events, the SDI demonstrated a longer duration.

\section{REFERENCES}

BORDI, I. A.; SUTERA, A. Drought monitoring and forecasting at large scale. In: ROSSI, G., VEGA, T.; BONACCORSO, B. (Ed.). Methods and tools for drought analysis and management. Water Science and Technology Library, Dordrecht, v. 62, p. 3-27, 2007. Available at: https://doi.org/10.1007/978-1-4020-5924-7_1. Accessed on: 15 Dec. 2018.

CAMPBELL, D.; BARKER, D.; MCGREGOR, D. Dealing with drought: small farmers and environmental hazards in Southern St. Elizabeth, Jamaica. Applied Geography, Oxford, GB, v. 31, n. 1, p. 1-16, 2011.

CHEN, A. A.; FALLOON, T.; TAYLOR, M. Monitoring agricultural drought in the West Indies. In: BOKEN, V. K.; CRACKNELL, A. P.; HEATHCOTE, R. L. (ed.). Monitoring and predicting agricultural drought: a global study. New York: Oxford University Press, 2005. p. 144-155.

CRAUSBAY, S. D.; RAMIREZ, A. R. Defining ecological drought for the twenty-first century. Bulletin of the American Meteorological Society, Boston, MA, v. 98, p. 2543-2550, 2017.

DIVA-GIS. Free spatial data by country. 2019. Available at: http://www.diva-gis.org/gdata. Accessed on: 1 Jan. 2019.

DROUGHT slows economic growth. Jamaica Observer, Kingston, Jamaica, WI, 23 Aug. 2014. Business. Available at: http://www.jamaicaobserver.com/business/Drought-slowseconomic-growth_17405601. Accessed on: 5 Jan. 2019.

EBI, K., L.; BOWEN, K. Extreme events as sources of health vulnerability: drought as an example. Weather and Climate Extremes, Sydney, NSW, AUS, v. 11, p. 95-102, 2016.

EM-DAT. The International Disaster Database. Centre for Research on the Epidemiology of Disasters-CRED. Emergency events database. Brussels, BEL: CRED: Université Catholique de Louvain, 2018. Available at: www.emdat.be. Accessed on: 2 Jan. 2019.

FULTON, L. Drought conditions and management strategies in Jamaica. 2013. Available at: http://www.droughtmanagement.info/literature/UNW-

DPC_NDMP_Country_Report_Jamaica_2013.pdf. Accessed on: 10 Feb. 2019.

GIBBS, W. J.; MAHER, J. V. Rainfall deciles as drought indicators. Bureau of Meteorology Bulletin, Melbourne, AUS, v. 33, n. 48, p. 1-117, 1967.

GIDDINGS, L.; SOTO, M.; RUTHERFORD, B. M.; MAAROUF, A. Standardized precipitation index zones for Mexico. Atmosfera, México, DF, v. 18, n. 1, p. 33-56, 2005.

MCKEE, T. B.; DOESKEN, N. J.; KLEIST, J. The relationship of drought frequency and duration to time scale. In: CONFERENCE ON APPLIED CLIMATOLOGY, 8.,1993, Anaheim, CA. Proceedings [...]. Anaheim: American Meteorological Society, 1993. p. 179-184.

MEEHL, G.A.; STOCKER, T. F.; COLLINS, W. D.; FRIEDLINGSTEIN, P.; GAYE, T.; GREGORY, J. M.; KITOH, A.; KNUTTI, R.; MURPHY, J. M.; NODA, A.; RAPER, S. C. B.; 
WATTERSON, I. G.; WEAVER, A. J.; ZHAO, Z. C. Global climate projections. In: SOLOMON, S.; QIN, D.; MANNING, M.; CHEN, Z.; MARQUIS, M.; AVERYT, K. B.; TIGNOR, M.; MILLER, H. L. (ed.). Climate change 2007: the physical science basis. Contribution of Working Group I to the Fourth Assessment Report of the Intergovernmental Panel on Climate Change. Cambridge, U.K.: Cambridge University Press, 2007. p. 747-845.

METEOROLOGICAL SERVICE OF JAMAICA. Mean Monthly Rainfall. Kingston, Jamaica, WI: MSJ, 2019. Available at: http://metservice.gov.jm/. Accessed on: 5 Jan. 2019.

NALBANTIS, I.; TSAKIRIS, G. Assessment of hydrological drought revisited. Water Resources Management, Athens, GRC, v. 23, n. 5, p. 881-897, 2008.

OTKIN, J. A.; SVOBODA, M.; HUNT, E. D.; FORD, T. W.; ANDERSON, M. C.; HAIN, C.; BASARA, J. B. Flash droughts: a review and assessment of the challenges imposed by rapid-onset droughts in the United States. Bulletin of the American Meteorological Society, Boston, MA, v. 99, n. 5, p. 911-919, 2018.

PETTITT, A. N. A non-parametric approach to the change point problem. Applied Statistics, Houghton, Ml, v. 28, p. 126-135, 1979.

QIN, D.; CHEN, Z.; AVERYT, K. B.; MILLER, H. L.; SOLOMON, S.; MANNING, M.; MARQUÍS, M.; TIGNOR, M. Summary for policymakers. In: SOLOMON, S.; QIN, D.; MANNING, M.; CHEN, Z.; MARQUÍS, M.; AVERYT, K. B.; TIGNOR, M.; MILLER, H. L. (ed.). Climate change 2007: the physical science basis. Contribution of working group I to the fifth assessment report of the Intergovernmental Panel on Climate Change. Cambridge: Cambridge University Press, 2007. p. 1 -18.

RICHARDS, J. F. Drought assessment tools for agricultural water management in Jamaica. 2010. Thesis (PhD of Science Bio Resources Engineering) - McGill University, Montreal, CAN, 2010. Available at: digitool.library.mcgill.ca > thesisfile97212. Accessed on: 20 Dec. 2018.

SPINONI, J.; NAUMANN, G.; CARRAO, H.; BARBOSA, P.; VOGT, J. et. al. World drought frequency, duration and severity for 1951-2010. International Journal of Climatology, Chichester, GB, v. 34, n. 8, p. 2792-2804, 2014.

TAYLOR, M. A.; ENFIELD, D. B.; CHEN, A. A. The Influence of the tropical Atlantic vs. the tropical Pacific on Caribbean Rainfall. Journal of Geophysical Research, Washington, US, v. 107, n. 9, p. 10-14, 2002.

THE DAILY GLEANER. 10,800 acres of crops hit by drought. Droughts in Jamaica. 1987. Newspaper Archive.

THE DAILY GLEANER. Agriculture taking a scorching. 1997. Newspaper Archive.

THE DAILY GLEANER. Drought bites into agriculture. 1998. Newspaper Archive.

THE DAILY GLEANER. Drought triggers citrus virus into epidemic. 1996. Newspaper Archive.

THE DAILY GLEANER. Water problems mount as drought continues. 1985. Newspaper Archive.

THE UNIVERSITY OF THE WEST INDIES. The Climate Studies Group Mona. Planning Institute of Jamaica. Near term climate scenarios for Jamaica (PIOJ), Kingston, 
Jamaica, 2014. Kingston, Jamaica, WI: The University of the West Indies, 2014. Summary for policymakers. Available at: https://www.pioj.gov.jm. Accessed on: 5 Jan. 2019.

TIGKAS, D.; VANGELIS, H.; TSAKIRIS, G. The drought indices calculator (DrinC). In: INTERNATIONAL CONFERENCE OF EWRA, 8., 2013, Porto, PT. Proceedings [...]. Porto: FEUP, 2013. p. 1333-1342. Tema: Water Resources Management in an Interdisciplinary and Changing Context.

TROTMAN, A., R. M.; GORDON, R. M.; HUTCHINSON, S. D.; SINGH, R.; MCRAE-SMITH, D. Policy responses to GEC impacts on food availability in the Caribbean community.

Environmental Science \& Policy, Exeter, GB, v. 12, n. 4, p. 529-541, 2009.

TSAKIRIS, G.; VANGELIS, H. Towards a drought watch system based on spatial SPI. Water Resources Management, Athens, GRC, v. 18, n. 1, p. 1-12, 2004.

WATER RESOURCES AUTHORITY - WRA. Services. 2019. Available at: https://www.wra.gov.jm/services/. Accessed on: 20 Nov. 2019.

WILHITE, D. A. Drought as a natural hazard: concepts and definitions. In: WILHITE, D. A. (ed.). Drought: a global assessment, natural hazards and disasters series. London, UK: Routledge Publishers, 2000. Chap. 1, p. 3-18.

WILHITE, D. A.; GLANTZ, M. H. Understanding the drought phenomenon: the role of definitions. Water International, Urbana, ILL, v. 10, p. 111-120, 1985.

WOLD, H. Non-linear iterative partial least squares (NIPALS) modelling: some current developments. In: KRISHNAIAH, P. R. (ed.). Multivariate analysis. New York: Academic Press, 1973. v. 3, p, 383-407.

WORLD METEOROLOGICAL ORGANIZATION - WMO; GLOBAL WATER PARTNERSHIP - GWP. Handbook of drought indicators and indices. Geneva: WMO, 2016. Integrated Drought Management Programme (IDMP). WMO-No. 1173. Available at:

http://www.droughtmanagement.info/literature/GWP_Handbook_of_Drought_Indicators_and_ Indices_2016.pdf. Accessed on: January 20, 2019.

YEVJEVICH, V. An objective approach to definition and investigations of continental hydrologic droughts. Hydrology Papers, Fort Collins, CO, v. 23, p. 1-25, 1967.

Recebido: junho de 2019. Aceito: novembro de 2019. 